\title{
Attitude towards Learning Chemistry among Secondary School Students in Malaysia
}

\author{
Farhana Wan Yunus, Zainun Mat Ali \\ Faculty of Education, \\ Universiti Teknologi MARA, Shah Alam 40200, Malaysia \\ farhana.wan.yunus@gmail.com
}

\begin{abstract}
In this current era, the world is facing environmental challenges where the future communities are losing interest in science subjects such as chemistry. There are many factors that contributed to students' success. One of the factors is the students' attitude in learning. The result of this study revealed that a majority of the students has a positive attitude towards learning chemistry when they conduct chemistry experiments in the laboratory. Students also show positive attitude towards teachers' teaching style. Result also revealed that most students have a negative attitude towards chemistry because they lack interest in the subject and the syllabus itself.
\end{abstract}

Keywords: Attitude, chemistry, future communities, environmental challenges

eISSN 2398-4295 @ 2018. The Authors. Published for AMER ABRA CE-Bs by e-International Publishing House, Ltd., UK. This is an open-access article under the CC BY-NC-ND license (http://creativecommons.org/licenses/bync-nd/4.0/). Peer-review under responsibility of AMER (Association of Malaysian Environment-Behaviour Researchers), ABRA (Association of Behavioural Researchers on Asians) and CE-Bs (Centre for EnvironmentBehaviour Studies), Faculty of Architecture, Planning \& Surveying, Universiti Teknologi MARA, Malaysia.

DOI: ttp://dx.doi.org/10.21834/ajbes.v3i9.61 


\subsection{Introduction}

In a normal education setting, teachers are concern about their students' grades. Most teachers hope their students will succeed. There are many factors that contributed to students' success. One of the factors is students' attitude in learning. Understanding students' attitude is essential in supporting students' achievement and interest toward a particular subject. A lot of students nowadays are losing interest in the science subjects such as chemistry. Attitudes of students could also be affected by the changing environment. Nowadays, young people all over the world are engrossed in computer gadgets and online social networking which may decrease their interest in learning science. This is an environmental challenge that the future communities are facing in this era.

\subsection{Literature Review}

The chemistry subject is introduced to Malaysian students during their upper secondary school. During the primary school and lower secondary school, the subject science in general is inserted in the school curriculum. Only when the students enter the upper secondary school that they learn chemistry, biology and physics in separate classes. One of the aims of chemistry curriculum for the secondary school students is to provide students with the knowledge and skills in science and technology. Chemistry is also vital to create awareness on the need to love and care for the environment and play an active role in its preservation and conservation for future communities (Curriculum Development Centre, 2005).

Koch (2005) said that teachers' feelings and attitudes about science can affect their students' feelings and attitudes. Students who reported having positive experiences during their science class were said to be influenced by their teachers' positive attitudes toward science. This is proven by a research done by Bauer (2002) that said, students' positive attitude was influenced by the teachers' enthusiasm, effectiveness in teaching and presentation on experiments. In accordance to Ward et al. (2005), attitudes of students towards science are formed at an early age. At an early age, parents and teachers can observe the students' attitude towards science. When the students show negative attitude in learning science, parents and teachers can take necessary actions to make the students have a positive attitude towards science. The chemistry syllabus and content are other factors that contributed towards students' negative attitude to chemistry. The students dislike science because of the amount of information they have to learn as well as the amount of time spent for writing in science classes (Pollard and Triggs (2000); Ward et al., 2005). According to Jegede (2007) and Edomwonyi-otu and Avaa (2011), a lot of students said that chemistry is too broad for them to learn in a short time. Students find it a bit difficult to learn chemistry because of its cramped syllabus. The Form Four chemistry syllabus in Malaysia requires nine chapters for students to master before their exam. A lot of chemistry teachers claim they have to make extra classes to cover all of the chapters in the syllabus. Students who truly want to learn will have little problem grasping the concepts. However, weak students will find chemistry exceedingly dull and dreary.

Peers and other students can also influence the students' attitude in learning chemistry. Other students' opinions on chemistry can affect students' attitude in learning chemistry (Berg 
et al., 2003). If a majority of the students in a school have a poor attitude and opinions in chemistry, other students are likely to have the same reaction towards the subject. Most of the times, students complain about the course content. They complain that chemistry is too difficult and takes a lot of time to study because of the weight of information the subject has (Pollard and Triggs, 2000; Ward et al., 2005). Knowing the basic and schemata of the subject is crucial to succeed. The use of a variety of teaching styles and methods can raise the students' attention and interest in chemistry. Teachers who failed to use an engaging teaching style during chemistry class will lose the students' attention as they can easily get bored. Some teachers find this a challenge because it is quite difficult to cater to each and every student's needs. When teachers put more effort in their teaching styles as well as put into concern the students' needs, it can boost the students' attitude towards chemistry.

The formation of students' positive attitude towards chemistry would require a lot of time and careful planning (Azman, 2003; Menis, 1983). Positive attitude towards learning chemistry cannot be formed over a short time. Therefore, the society at large, namely the education boards, teachers and parents, have to link hands and ideas to overcome this environmental challenges of negative attitude toward learning chemistry. This is to ensure future communities that are balanced in sciencetif knowledge as well as technology, social, humanities and other subjects in this world for a better future ahead.

\subsection{Methodology}

The study employed is a descriptive research. Questionnaires regarding 'Students' attitude towards learning chemistry' were distributed randomly to 100 form four students. The students are studying chemistry as one of their subjects at a public secondary school in Malaysia. However, the questionnaires were completed and returned by 80 students only. The questionnaire was adapted from the 'The biology attitude scale' by Russell and Hollander (1975) and 'Causes of students anxieties' by Jegede (2007). The students' age ranges from 15-16 years old.

The questionnaire was designed to study the students' attitude towards learning chemistry. The first research question was to identify the positive and negative attitude among urban secondary school students towards learning chemistry. The second research question was intended to find out the factors that contributed to students' positives and negatives attitude towards chemistry. The questionnaire was divided into three parts which were called as Part A, Part B and Part C. Part A consisted of demographic data. Part B contained twenty questions on positive and negative attitudes of students in learning chemistry. Part $C$ comprised of twenty-four questions on the factors that contributed to students' positives and negatives attitude towards chemistry. A Likert scale with a four point system was used to measure responses on the questionnaire. The respondents indicate their opinion by circling a number in the column adjacent to the statement. Items were scored on the following keys: 1 - Strongly Agree, 2 - Agree, 3 - Disagree, and 4- Strongly Disagree. 


\subsection{Findings and Analysis}

As of late, it seems that not many students enrolled in chemistry courses in universities. Students might not be interested in chemistry or they did not reach the qualification to be accepted in the chemistry courses in universities. Statistics on students' enrollment was obtained from a public university in Selangor, Malaysia. Table 1 below shows the number of students who enrolled in three science courses at a public university in Selangor, Malaysia. In July 2010, 80 students enrolled in the Bachelor of Science (Chemistry). However, in December 2010, the students who enrolled in the course has decrease to 33 students. In September 2011, 36 students enrolled in the course and then it has decreased to 28 students in March 2012. For the Bachelor of Science (Applied Chemistry), 85 students enrolled in the course in July 2010, followed by 0 students in December 2010 and 80 students in September 2011. Nevertheless, the number of students dropped down to 35 students in March 2012. No student enrolled in the Bachelor of Education (Chemistry) in July 2010. In December 2010, 12 students enrolled in the course and then it increased to 26 students in September 2011 followed by no student at all in March 2012.

Table 1: Number of students who enrolled in three science courses between July 2010 - March 2012. July $2010 \quad$ December $2010 \quad$ September $2011 \quad$ March 2012

Bachelor of Science

(Chemistry)

Bachelor of Science

(Applied Chemistry)

Bachelor of

Education

(Chemistry)
80

85

0

12
36

80

26
28

35

0

The finding of this statistic is alarming because it shows the decreasing number of chemistry students in one local university in Malaysia. It is a current environmental challenge to get many students to be interested in chemistry courses in universities. As said by Ward et al. (2005), interest in chemistry must be instilled from young in the students' life so that they will continue the interest to a higher level, namely the university level and their future career.

Result of the study revealed that a majority of the students has a positive attitude towards chemistry when they conduct experiments in the laboratory. Table 2 below shows the students' attitude when doing chemistry experiments. $85 \%$ of the students $(28.8 \%$ strongly agree and $56.2 \%$ agree) show positive attitude when conducting experiments while only $15 \%$ ( $12.5 \%$ disagree and $2.5 \%$ strongly disagree) of the students have a negative attitude towards conducting chemistry experiments.

Table 2: Conducting chemistry experiments make me happy.

\begin{tabular}{cccc}
\hline Strongly Agree & Agree & Disagree & Strongly Disagree \\
\hline $28.8 \%$ & $56.2 \%$ & $12.5 \%$ & $2.5 \%$ \\
\hline
\end{tabular}


Majority of the students said that at times, the chemistry subject can be too dry and uninteresting. Conducting experiments in the laboratory can enhance students' understanding because they can apply the theory that they have learnt in the classroom into the experiments. The result of this study shows that students love hands-on learning rather than chalk and talk learning. The students are most happy when they get to conduct experiments in the lab. The result of this study is in line with other researches where chemistry experiments are enjoyed by the students (Jegede, 2007; Blosser, 1990). Experiments can give more detailed information about chemistry and can enhance the students' interest in learning chemistry (Blosser, 1990; Yahaya and Ling, 2010).

While conducting experiments may make students have a positive attitude towards chemistry, the subject itself gives a negative attitude towards learning chemistry. Based on table 3 below, $63.8 \%$ (50\% disagree and $13.8 \%$ strongly disagree) of the students gave a negative respond about the statement "I like chemistry more than any other subjects in school". This study shows that $63.8 \%$ of the respondents have a negative attitude towards chemistry because they prefer other subject than chemistry. Only $36.2 \%$ of the students ( $8.8 \%$ strongly agree and $27.4 \%$ agree) showed a positive attitude by claiming that they like chemistry more than any other subjects in school.

Table 3: I like chemistry more than any other subjects in school.

\begin{tabular}{cccc}
\hline Strongly Agree & Agree & Disagree & Strongly Disagree \\
\hline $8.8 \%$ & $27.4 \%$ & $50 \%$ & $13.8 \%$ \\
\hline
\end{tabular}

According to Nordin and Chin (2010), the students' achievement in chemistry is related to their level of interest in the subject. It can be inferred that students who do not have the passion for chemistry may not be able to score high in chemistry exams. Through classroom observation, students who are not interested in chemistry do not pay attention when the teacher is teaching. Chemistry involves calculation and reading. Students who are learning chemistry are forced to use their right and left brains together. A lot of students find the subject difficult because they have to be competent in both calculation and reading. Students who like to do calculation will suffer when the teacher teaches about definitions, process, principles and facts. The same goes to students who prefer to read more than doing calculation. The students might be left behind when the teacher focuses on the calculation. This is one of reasons why many students are not interest chemistry.

According to table 4 below, majority of the students, which is $80 \%(23.8 \%$ strongly agree and $56.2 \%$ agree) of the whole student sample, claimed that they are happy when their chemistry teacher shares his or her knowledge and expertise about the subject.

Table 4: My chemistry teacher shares his or her knowledge and expertise with the students.

\begin{tabular}{cccc}
\hline Strongly Agree & Agree & Disagree & Strongly Disagree \\
\hline $23.8 \%$ & $56.2 \%$ & $15 \%$ & $5 \%$ \\
\hline
\end{tabular}

From the study, the most influential factor that contributed to students' positive attitude 
towards learning chemistry is when the teachers are an expert in the subject. It has been observed that students like it when teachers share their knowledge and expertise about the lesson being taught. It is easier for students to ask for ideas, opinions and questions on the subject because they can get the answer back immediately. This can enhance the students' understanding in chemistry.

Table 5 below shows the most influential factor that contributed to students' negatives attitude towards chemistry. Only $28.8 \%$ (5\% strongly agree and $23.8 \%$ agree) of the students claimed that the chemistry syllabus is not too wide for them. Most of the students, which is $71.2 \%$ ( $50 \%$ disagree and $21.2 \%$ strongly disagree) of the whole student sample, said that chemistry syllabus is too wide.

Table 5: Chemistry syllabus is not too wide.

\begin{tabular}{cccc}
\hline Strongly Agree & Agree & Disagree & Strongly Disagree \\
\hline $5 \%$ & $23.8 \%$ & $50 \%$ & $21.2 \%$ \\
\hline
\end{tabular}

This finding corresponds with previous studies that claimed chemistry syllabus is too wide (Jegede, 2007; Edomwonyi-otu and Avaa, 2011). There are nine chapters of the chemistry subject in the Malaysian secondary school syllabus. To finish the syllabus, the teachers have to teach at a speedy rate, which in the end is useless because students cannot digest information at a fast pace. Most of the students in this study said that the chemistry syllabus is too wide for them. On top of knowing how to do calculations, the students must also understand and remember the concepts, processes and scientific theories in the chemistry lesson. Before the students could go to the next topic or lesson, they must first master the previous lesson. The students feel pressured because there are a lot of topics to study in chemistry before they can move to the next topic.

\subsection{Conclusion}

Hence, the result of the present study showed that most of the students have a positive attitude towards learning chemistry when their teachers allow them to conduct chemistry experiments in the laboratory. Conversely, students do not show a positive attitude when they are asked to listen to what the teacher is teaching in front. This shows that students in this present study prefer to do hands-on activities or student centered learning rather than teacher centered learning. Even though the students said they love doing chemistry experiments in the laboratory, the students will not enjoy doing it if the teachers are not knowledgeable. Teachers who are well experienced and an expert in the area can answer the students' questions remarkably well as oppose to teachers who are inexperience. In addition to that, teachers who are enthusiastic and motivated in their teaching can raise the students' interest in the subject no matter how difficult the lessons are. Furthermore, students are more cooperative in class when teachers are enthusiastic in teaching them (Urban, 2008; Koch, 2005; Bauer, 2002). Majority of the students claimed that chemistry is not their favourite subject in school. The factor that contributed to this negative attitude is the fact that the chemistry subject is too wide for students to learn before their exam. Both teachers and 
students are complaining that there are too much to learn, but time is limited. Teachers have to work overtime while the students have to remain in school after school hours for extra chemistry classes so that the teacher can finish off the chemistry syllabus.

This study comes with several recommendations. Future researchers should do a thorough research and interview the students on why they dislike chemistry. The present study did not interview the students. Therefore, this research lacks rich data that could have enhanced the findings. Students' negative attitude towards chemistry in school is a powerful influence to their choices of courses in university in the future. If a majority of the students has a negative attitude towards chemistry at school, how could universities expect a lot of students to apply for chemistry courses? It is worrying to know that only a few people will be good in chemistry in the future. This issue is a challenge to overcome. Apart from that, this study did not look at gender differences. Interested researchers should compare and contrast the preferences of male and female students as well as their positive and negative attitude towards learning chemistry. It would be beneficial to know which gender has more positive and more negative attitude towards learning chemistry in secondary school in Malaysia.

In conclusion, the results of the present study found chemistry students are decreasing in a local university in Malaysia. Finding of the research showed that the majority of the respondents has a positive attitude towards chemistry when they get to do experiments. The students claimed that the factor of this positive attitude is when their chemistry teachers are experts in the subject. Yet, these students still show a negative attitude towards the chemistry subject. The factor for their negative attitude is the chemistry syllabus itself because the students said it is too broad for them to handle in a limited time. Consequently, the current communities especially researchers, ministry of education, parents and teachers have to find out ways to overcome this environmental challenge and increase the students' interest in chemistry at the school level. When students are motivated and interested to learn chemistry from young, they may continue to learn it later on in universities which will benefit the future communities and the world at large.

\section{References}

Azman, J. (2003). Sikap pelajar terhadap fizik di sekolah kawasan felda. Jurnal Penyelidikan MPSAH, 7, 19-27.

Bauer, C. F. (2002). What students think: College students describe their high school chemistry class. Science Teacher, 69, 52-55.

Berg, C., Bergendahl, V., Lundberg, B. \& Tibell, L. (2003). Benefiting from an open-ended experiment? A comparison of attitudes to, and outcomes of, an expository versus an open-inquiry version of the same experiment. International Journal of Science Education, 25, 351-372.

Blosser, P. E. (1990). The Role of Laboratory Science Teaching. Columbia Ohio State University.

Curriculum Development Centre. (2005). Integrated curriculum for secondary schools curriculum specifications, Chemistry form 4. Last retrieved on (15 July 2012) from http://www.smkpp14.net/web_documents/hsp_chemistry_f4.pdf 
Edomwonyi-otu, L. and Avaa, A. (2011). The challenge of effective teaching of chemistry: A case study. Leonardo Electronic Journal of Practices and Technologies, 10 (18), 1-8.

Jegede, S. A. (2007). Students' anxiety towards the learning of Chemistry in some Nigerian secondary schools. Educational Research and Review, 2 (7), 193-197.

Koch, J. (2005). Science stories: science methods for elementary and middle school teachers. (3rd ed.). New York: Houghton Miffin Company.

Menis, J. (1983). Attitudes towards chemistry as compared with those towards mathematics, among tenth grade pupils 9aged 15) in high level secondary schools in Israel. Research in Science and Technological Education, 1, 185-191.

Nordin, A. and Chin, M. T. (2010). Pemahamaan Konsep Pelajar Tingkatan Empat Dalam Tajuk Ikatan Kimia Di Skudai Johor. Pemahamaan Konsep Pelajar Tingkatan Empat Dalam Tajuk Ikatan Kimia Di Skudai Johor. pp. 1-10. Last Retrieved on (4 ${ }^{\text {th }}$ August 2012) from http://eprints.utm.my/11251/

Pollard, A. \& Triggs, P. with Broadfoot, P., McNess, E. and Osborn, M. (2000). What Pupils Say: Changing Policy and Practice in Primary Education. London: Continuum.

Russell, J. \& Hollander, S. (1975). A biology attitude scale. The American Biology Teacher, 37 (5), 270-273. Urban, H. (2008). Lessons from the classroom. California: Great Lessons Press.

Ward, H., Roden, J., Hewlett, C. \& Foreman, J. (2005). Teaching science in the primary classroom: A practical guide. London: Paul Chapman Publishing.

Yahya, A. \& Ling, Y. Y. (2010). Kepentingan Amali Kimia. Last Retrieved on (30th July 2012) from http://eprints.utm.my/10416/1/1.10_Kepentingan_Amali_Kimia.pdf 